\title{
CLINICAL EFFECT OF PHYSICAL EXERCISE ON DISEASE PREVENTION IN COLLEGE STUDENTS
}

EFEITO CLÍNICO DO EXERCICIO FÍSICO COMO PREVENÇÃO DE DOENÇAS EM ESTUDANTES UNIVERSITÁRIOS

\section{EFECTO CLIINICO DEL EJERCICIO FISICO COMO PREVENCIÓN DE ENFERMEDADES EN ESTUDIANTES} UNIVERSITARIOS

Yongcai Zheng' (iD

(Physical Education Professional)

1. Xi'an Medical University, Xi'an, Shaanxi, China.

\section{Correspondence:}

Yongcai Zheng

Xi'an, Shaanxi, China. 710021

youning1015520@163.com

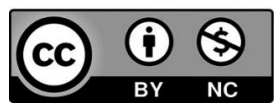

\begin{abstract}
Introduction: College students face increasing pressure in all aspects of study and life. They urgently need a way to relieve stress. Physical exercise is the best choice for college students to relieve stress. Objective: To explore the relationship between physical exercise and disease prevention in college students. Methods: The article conducts a logistic regression analysis of physical exercise in college students and analyzes the relationship between the physical exercise factors and the occurrence of physical diseases. Results: The incidence of disease in students participating in physical exercise is low. The prevalence of diabetes, obesity, and hyperlipidemia decreased with the increase of physical activity intensity. Conclusion: Diligently participation in physical exercises can help college students resist diseases. Level of evidence Il; Therapeutic studies investigation of treatment results.
\end{abstract}

Keywords: Health of students; Aerobic exercises; Physical activity.

\section{RESUMO}

Introdução: Os estudantes universitários enfrentam pressão crescente em todos os aspectos do estudo e da vida. Eles precisam com urgência de um modo de aliviar o estresse. Nesse caso, o exercício físico é a melhor escolha para aliviar o estresse. Objetivo: Explorar a relação entre exercício físico e prevenção de doenças em estudantes universitários. Métodos: $O$ artigo consiste de análise de regressão logística do exercício físico em universitários e investiga a relação entre o exercício físico e a ocorrência de doenças físicas. Resultados: A incidência da doença em alunos que praticam exercícios físicos é baixa. A prevalência de diabetes, obesidade e hiperlipidemia diminuiu com o aumento da intensidade da atividade física. Conclusões: A participação diligente em exercícios físicos pode ajudar os estudantes universitários a serem mais resistentes a doenças. Nível de Evidência ll; Estudos terapêuticos - Investigação dos resultados do tratamento.

Descritores: Saúde do estudante; Exercício aeróbico; Atividade física.

\section{RESUMEN}

Introducción: Los estudiantes universitarios se enfrentan a una presión cada vez mayor en todos los aspectos del estudio y la vida. Necesitan urgentemente una forma de aliviar el estrés. En este caso, el ejercicio físico es la mejor opción para dicha tensión. Objetivo: Explorar la relación entre ejercicio físico y prevención de enfermedades en estudiantes universitarios. Métodos: El artículo consiste en un análisis de regresión logística del ejercicio físico en estudiantes universitarios e investiga la relación entre el ejercicio físico y la aparición de enfermedades físicas. Resultados: La incidencia de enfermedades en los estudiantes que practican ejercicio es baja. La prevalencia de enfermedades como diabetes, obesidad e hiperlipidemia disminuyó al aumentar la intensidad de la actividad física. Conclusiones: La práctica rutinaria de actividades físicas puede ayudar a los estudiantes universitarios a ser más resistentes a las enfermedades. Nivel de Evidencia ll; Estudios terapéuticos - Investigación de los resultados del tratamiento.

Descriptores: Salud del estudiante; Ejercicio aeróbico; Actividad física.

\section{INTRODUCTION}

With the development of society, people's lifestyles and leisure physical activity patterns have undergone major changes. The sit-in lifestyle has become a worldwide public health problem. Studies at home and abroad have shown that different intensities of physical activity in the population are related to the occurrence and death of chronic diseases. ${ }^{1}$ Moderate physical activity is most beneficial to health. A sedentary lifestyle is an important risk factor for chronic diseases such as cardiovascular and cerebrovascular diseases. This article uses the survey data of nutrition and health status to analyze college students' physical exercise status quo and its influencing factors. In this way, the population's relationship between physical activity, physical exercise, and chronic diseases such as hypertension, diabetes, obesity, and hyperlipidemia are discussed.

\section{METHOD}

\section{Research object}

We use the principle of multi-stage stratified cluster sampling to select 5,760 people from 16 classes of different economic development 
levels and types for investigation. ${ }^{2}$ This article selects 18-23-year-old college students as the analysis object. The total number is 11178 people. Among them, 5,418 are males, and 5,760 are females

\section{Methods Questionnaire survey, medical examination}

We use the workshop manual and quality control plan for Chinese college students' nutrition and health status survey.

\section{Diagnostic criteria}

High blood pressure, diabetes, and hyperlipidemia shall be diagnosed by hospitals at or above the township level. Obesity diagnosis adopts the WGOC standard. ${ }^{3}$ For the grading standard of physical exercise and physical activity intensity, please refer to the Work Manual of the Survey of Nutrition and Health Status of Chinese College Students.

\section{Statistical analysis model of sports skill ability assessment}

We conduct feature mining and pattern training on the evaluation data of sports skills. The article adopts field-habituation theory to evaluate sports skills and abilities. ${ }^{4}$ According to the statistical characteristics of big data, a statistical analysis model for evaluating sports skills and ability is established. Then we build a feature extraction model for the statistical analysis of sports skills and capabilities to obtain a statistical sample sequence of sports skills and capabilities:

$$
Q\left(a, b_{i}\right)=\sum_{i} \sum_{j}\left[y_{i j}-\left(\hat{a} x_{i j}+\hat{b}_{i}\right)\right]^{2}
$$

Formula (1) When taking the smallest value, the statistical feature quantity of sports skill ability is obtained and satisfies the following relationship

$$
\left\{\begin{array}{l}
\frac{\partial Q}{\partial \hat{a}}=-\sum_{i} \sum_{j} 2\left[y_{i j}-\left(\hat{a} x_{i j}+\hat{b}_{i}\right)\right] x_{i j}=0 \\
\frac{\partial Q}{\partial \hat{b}_{i}}=-\sum_{i} \sum_{j} 2\left[y_{i j}-\left(\hat{a} x_{i j}+\hat{b}_{i}\right)\right]=0
\end{array}\right.
$$

When $Q$ reaches the minimum, we get the fuzzy correlation evaluation set of sports skill ability evaluation. ${ }^{5}$ We use the association rule mining method to obtain the statistical characteristics of sports skill ability evaluation as:

$\left\{\begin{array}{l}\hat{a}=\frac{\sum_{i} \sum_{j}\left(x_{i j}-\bar{x}_{i}\right)\left(y_{i j}-\bar{y}_{i}\right)_{i}}{\sum_{i} \sum_{j}\left(x_{i j}-\bar{x}_{i}\right)^{2}} \\ \hat{b}_{i}=y_{i}-a \bar{x}_{i}\end{array}\right.$

Among them, $\bar{x}_{i}=\frac{1}{j} \sum_{i} x_{i j}, \bar{y}_{i}=\frac{1}{j} \sum_{i} y_{i j}, j$ is the scalar coordinate sequence collected by the statistical sample sequence of sports skills and ability. The article takes $m$ as the embedding dimension. $s_{i}=\left(s_{i}, x_{i+v^{*}} \ldots, x_{i+(m-1) \tau}\right)^{T}$ represents the fuzzy evaluation subset. According to the above analysis, the regular feature quantity of cross-correlation information fusion is evaluated to measure sports skills and abilities. ${ }^{6}$ We use this as a constraint to evaluate and analyze the characteristics of sports skills. Then we establish a set of fuzzy association rules for the evaluation of sports skills and abilities.

\section{Statistical processing data}

We use the Eplinfo6 entry. After logical error detection and cleaning, SAS software is used for statistical analysis. The $x 2$ test was used for the comparison of sample rates. The article uses Logistic regression to comprehensively analyze the relationship between various factors and exercise and chronic diseases.

\section{RESULTS}

\section{Physical exercise of college students}

\section{Physical exercise of different ages and genders}

The total participation rate of the sample college students in physical exercise is $11.97 \%, 11.04 \%$, and $12.85 \%$ for males and females, respectively. ${ }^{7}$ The difference between the two is significant $(x 2=8.6797$, $\mathrm{P}=0.0032)$. Whether the participation rate of male and female physical exercise increases with age, the 23-year-old group reaches the highest. The trend test is statistically significant $(P<0.01)$. (Table 1)

The participation rate of physical exercise of different education levels

As the level of education increases, the participation rate of college students in sports is on the rise. ${ }^{8}$ The participation rate of physical exercise among illiterate, elementary school, junior high school, high school, college, university, and above college students was $6.26 \%, 8.86 \%, 11.43 \%$, $21.33 \%, 34.81 \%$, and $36.36 \%$. The trend was statistically significant after testing $(X 2=805.70, P<0.001)$.

The difference in physical exercise between urban and rural college students

The participation rates of urban and rural college students in sports were $32.39 \%$ and $2.38 \%$, respectively. The difference was statistically significant $(X 2=2087.01, P<0.0001)$.

The intensity of light, moderate, and severe physical activity in different sports situations

The exercise participation rate of college students decreased successively $(17.46 \%, 4.04 \%$, and $1.67 \%)$, and the difference was statistically significant. $(X 2=478.45, \mathrm{P}<0.001)$.

Logistic regression analysis of the influence of various factors on physical exercise

We used whether to participate in physical exercise as the dependent variable, gender, age, education level, urban and rural residence, and physical activity intensity as independent variables for Logistic regression analysis. At the same time, we observe the independent effect of each factor on physical exercise after adjusting for other factors. ${ }^{9}$ The results show that the participation rate of college students in physical exercise increases with age and educational level and decreases with the increase in physical activity intensity. The participation rate of college students in physical exercise is higher in cities than in rural areas, and there is no difference between men and women. (Table 2)

\section{The relationship between physical exercise and chronic diseases}

We use one or more chronic diseases (hypertension, diabetes, obesity, and hyperlipidemia) as the dependent variable. Logistic regression

\begin{tabular}{|c|c|c|c|c|c|c|}
\hline \multirow[b]{2}{*}{ Age } & \multicolumn{2}{|r|}{ Male } & \multicolumn{2}{|r|}{ Female } & \multicolumn{2}{|r|}{ Total } \\
\hline & $N$ & $\begin{array}{c}\text { Participation } \\
\text { Rate }\end{array}$ & $N$ & $\begin{array}{c}\text { Participation } \\
\text { Rate }\end{array}$ & $N$ & $\begin{array}{c}\text { Participation } \\
\text { Rate }\end{array}$ \\
\hline 18 & 678 & 3.54 & 795 & 2.26 & 1473 & 2.85 \\
\hline 19 & 1286 & 2.72 & 1453 & 4.2 & 2739 & 3.5 \\
\hline 20 & 1220 & 3.77 & 1301 & 7.61 & 2521 & 5.75 \\
\hline Twenty one & 1003 & 11.17 & 1071 & 19.51 & 2074 & 15.48 \\
\hline Twenty two & 766 & 29.24 & 749 & 35.38 & 1515 & 32.28 \\
\hline Twenty three & 487 & 32.85 & 414 & 21.26 & 901 & 27.53 \\
\hline$x$ trend & \multicolumn{2}{|r|}{712.01} & \multicolumn{2}{|r|}{790.69} & \multicolumn{2}{|r|}{1492.02} \\
\hline$P$ & \multicolumn{2}{|r|}{$<0.001$} & \multicolumn{2}{|r|}{$<0.001$} & \multicolumn{2}{|r|}{$<0.001$} \\
\hline
\end{tabular}
analysis was conducted with gender, age, education level, urban and

Table 1. A participation rate of physical exercise by gender and age (\%). 
rural residence, economic income level, physical activity intensity, and physical exercise as independent variables. ${ }^{10}$ Then we observe the independent effects of physical activity and physical exercise on chronic diseases after adjusting for other factors. The results showed that the protective factor that was statistically significant with chronic diseases was physical activity. The risk factor is physical exercise. (Table 3)

\section{The relationship between the prevalence of chronic diseases and the intensity of physical activity}

The prevalence of hypertension, diabetes, obesity, and hyperlipidemia decreased with increased physical activity intensity. After the trend test, there were statistical differences. (Table 4)

Table 2. Logistic regression analysis of physical exercise.

\begin{tabular}{c|c|c|c|c|c}
\hline Variable & B & Sx & P & OR & OR95\%Cl \\
\hline Gender & 0.083 & 0.0674 & 0.2184 & 1.087 & $0.952-1.240$ \\
\hline Age & 0.0424 & 0.00219 & $<0.001$ & 1.043 & $1.039-1.048$ \\
\hline $\begin{array}{c}\text { Education } \\
\text { Manual labor in urban } \\
\text { and rural areas }\end{array}$ & 0.3682 & 0.0288 & $<0.001$ & 1.445 & $1.366-1.529$ \\
\hline Activity intensity & 0.3723 & 0.00925 & $<0.001$ & 0.788 & $0.774-0.802$ \\
\hline
\end{tabular}

Table 3. Logistic regression analysis of chronic diseases.

\begin{tabular}{c|c|c|c|c|c}
\hline Variable & B & Sx & P & OR & OR95\%Cl \\
\hline Gender & 0.0591 & 0.06 & 0.3251 & 1.061 & $0.943-1.193$ \\
\hline Age & 0.0495 & 0.0021 & $<0.001$ & 1.051 & $1.047-1.055$ \\
\hline Education & -0.0004 & 0.0281 & 0.9901 & 1 & $0.946-1.056$ \\
\hline income & 0.0491 & 0.0202 & 0.0154 & 1.05 & $1.009-1.093$ \\
\hline $\begin{array}{c}\text { Manual labor in urban } \\
\text { and rural areas }\end{array}$ & -0.0539 & 0.0083 & $<0.001$ & 0.948 & $0.932-0.963$ \\
\hline Activity intensity & -0.3884 & 0.0505 & $<0.001$ & 0.678 & $0.614-0.749$ \\
\hline Exercise & 0.4923 & 0.0683 & $<0.001$ & 1.636 & $1.431-1.870$ \\
\hline
\end{tabular}

Table 4. Physical strength and prevalence of chronic diseases (\%).

\begin{tabular}{c|c|c|c|c|c}
\hline Strength & Sample size & Diabetes & Hypertension & Obesity & Hyperlipidemia \\
\hline Mild & 6529 & 2.67 & 6.16 & 3.86 & 3 \\
\hline Moderate & 3095 & 0.48 & 3 & 3 & 1 \\
\hline Severe & 1495 & 0.67 & 2.61 & 2.61 & 0.87 \\
\hline X2 trend & & 10336.34 & 7616.429 & 9123.329 & 9977.275 \\
\hline P value & & $<0.0001$ & $<0.0001$ & $<0.0001$ & $<0.0001$ \\
\hline
\end{tabular}

\section{DISCUSSION}

The male and female physical exercise rates of college students were $11.04 \%$ and $12.85 \%$, respectively. It is far below the level of college students in Guangdong Province. Participants of different age groups have the highest exercise rate among those over 23 , and the exercise rate of college students under 22 is less than $10 \%$. The participation rate of rural college students in physical exercise is only $2.38 \%$. This may be due to differences in the life rhythm, physical condition, self-care knowledge and awareness, physical exercise atmosphere, and facility accessibility among college students in different age groups and regions.
Logistic regression analysis showed that physical activity was a protective factor for chronic diseases, and physical exercise was a risk factor. This is inconsistent with the conclusions of some documents. It may be because, for a specific person, it shows that the hospital-based model has a higher hospitalization rate than the CDC-based model. However, in the three models, the total cost of treatment is the highest proportion of hospitalization expenses. This shows that the hospitalization fee has a greater impact on the total cost. The hospitalization rate of $24.2 \%$ also illustrates the general phenomenon of hospitalization of tuberculosis cases across the province. The proportion of supplementary drug costs exceeds the cost of anti-tuberculosis drugs. The cost of anti-tuberculosis drugs, the main expenditure for treating tuberculosis, is only ranked fourth.

The free quota provided by the state accounts for an average of $17.2 \%$ of the total cost of case treatment. The case itself has to bear $82.8 \%$ of the total cost. $53.1 \%$ of tuberculosis cases belonged to rural college students. Their families' average annual net income is much lower than the per capita disposable income of urban college students. The proportion of expenditures for illness is almost relative to the patient's one-year income. This accounts for more than half of the family's annual net income.

The regular treatment is negatively correlated with the patient's disease treatment cost because of the rough treatment. The cost of treatment is relatively low. Because the treatment was discontinued, the duration of treatment learned was relatively short. Because rough treatment leads to poor treatment effects and increased drug resistance rates, it will eventually lead to an increase in the treatment costs of patients.

Compared with 2019, the total per capita treatment cost for tuberculosis is $28.6 \%$ longer. This is lower than the $107.02 \%$ growth rate of GDP per capita. This shows that efforts have been made to control the increase in case costs. Therefore, the patient's acceptance of treatment costs reached $66.4 \%$. This shows that the government's reduction and exemption policy is still deeply rooted in the people's hearts. It also shows that the province's prevention and control agencies have made many efforts in tuberculosis control. However, the phenomenon of high hospitalization rate, high hospitalization cost, and high adjuvant drug fee is not only a phenomenon unique to tuberculosis diagnosis and treatment. Still, it should be considered in conjunction with the overall medical environment.

\section{CONCLUSION}

Moderate physical exercise can improve physical and mental quality and is the best way to resist and control physical and mental diseases. This article elaborates on the prevention and control of diseases from physical exercise and the precautions for physical exercise. The article results show that regular physical exercise has a good effect on disease prevention and control.

The author declare no potential conflict of interest related to this article

AUTHORS' CONTRIBUTIONS: The author made significant contributions to this manuscript. Yongcai Zheng: writing and performing surgeries; data analysis and performing surgeries; article review and intellectual concept of the article.

\section{REFERENCES}

1. Thomas EV, Warren-Findlow J. Body image, self-esteem, and behavioral risk for chronic disease among college students: Additional evidence for integrated prevention. J Am Coll Health. 2020;68(6):658-65.

2. Wang J. The association between physical fitness and physical activity among Chinese college students. J Am Coll Health. 2019;67(6):602-9.

3. Jao NC, Robinson LD, Kelly PJ, Ciecierski CC, Hitsman B. Unhealthy behavior clustering and mental health status in United States college students. J Am Coll Health. 2019;67(8):790-800.

4. Grasdalsmoen M, Eriksen HR, Lønning KJ, Sivertsen B. Physical exercise, mental health problems, and suicide attempts in university students. BMC Psychiatry. 2020;20(1):1-11.

5. Dominski FH, Brandt R. Do the benefits of exercise in indoor and outdoor environments during the COVID-19 pandemic outweigh the risks of infection?. Sport Sci Health. 2020;16(3):583-8.
6. Zhang Z, Chen B, Chen W. The mediating effect of perceived health on the relationship between physical activity and subjective well-being in Chinese college students. J Am Coll Health. 2021;69(1):9-16.

7. Yan Z, Harrington A. Factors that predict weight gain among first-year college students. Health Educ J. 2020;79(1):94-103.

8. Arsandaux J, Montagni I, Macalli M, BouteloupV, Tzourio C, Galéra C. Health risk behaviors and self-esteem among college students: systematic review of quantitative studies. Int J Behav Med. 2020;27(2):142-59.

9. Otundo JO, MacGregor SK. Effect of Situational Interest and Social Support on College Students' Physical Activity Motivation: A Mixed Methods Analysis. Phys Ed. 2019;76(2): 502-23.

10. Schultchen D, Reichenberger J, MittIT, Weh TR, Smyth JM, Blechert J, et al. Bidirectional relationship of stress and affect with physical activity and healthy eating. Br J Health Psychol. 2019;24(2):315-33 